九州大学学術情報リポジトリ

Kyushu University Institutional Repository

\title{
Poets on the Periphery: Kūkai' s Vision of Frontier Governance
}

Matsuda, Wi lliam

Sichuan University : Associate Professor of Japanese Language and Literature

https://doi.org/10.5109/2231577

出版情報: Journal of Asian Humanities at Kyushu University. 4, pp.21-37, 2019-03. Kyushu University, School of Letters, Graduate School of Humanities, Faculty of Humanities バージョン:

権利関係 : 


\section{Poets on the Periphery: Kūkai's Vision of Frontier Governance}

WILLIAM MATSUDA

\section{Introduction}

D URING the early ninth century, northeastern Japan was a liminal space not completely under the control of the Heian capital (Heiankyo ${ }^{1}$ 平 安京). Although the Japanese had made numerous attempts to pacify and colonize the eastern hinterlands since the seventh century, frequent uprisings by the Emishi 蝦夷, an ethnic group not recognized as Yamato 大和 Japanese, ${ }^{2}$ were a constant source of irrita-

The author wishes to express his sincere gratitude to the anonymous reviewer for their invaluable insights and advice.

1 In 794, Emperor Kanmu 桓武 (735-806; r. 781-806) moved the capital to Heiankyō (present-day Kyoto City) from its former location at Nagaokakyō 長岡京 (present-day Nagaokakyō City, Kyoto Prefecture).

2 There is a lack of consensus among historians and archaeologists as to the exact identity of the Emishi. Some suggest that they were genetically different from the Japanese and are closer to the Ainu, others suggest that they were "uncivilized Japanese," while others hypothesize that they were a mix of the two. Anthropologist Hanihara Kazuo proposes that the Emishi represent a stage where the Ainu and non-Ainu Japanese separated from their common ancestor, the Jomonese. Hanihara, "Emishi, Ezo, and Ainu," p. 46.

In the texts presented below, Kükai does not actually use the word "Emishi," but instead uses the Chinese names for peripheral barbarians (details below) or simply Hairy People (Jp. mōjin Ch. maoren 毛人). For the purposes of this study, an "Emishi" is anyone who lived along Japan's northeastern frontier, did not tion. Since the Taika 大化 Reforms of 645 , the region was nominally incorporated into the Japanese state and christened Mutsu 陸奥 Province, but government control remained tenuous. In the government halls of Heiankyō, far removed from the action on the frontier, Mutsu's status in the Heian state was perhaps one more of perception and imagination than reality.

Court-sanctioned histories narrate details of specific encounters with the periphery-dates, locations, and casualties - but literary writings also provide insight into the underlying ideologies, and how they were transformed over time. The "border guards" (sakimori 防人) poems found in the eighth-century poetic anthology Man'yōshū 万葉集 (Anthology of Myriad Leaves, ca. 759) depict the frontier in romantic terms, focusing on such themes as homesickness or longing for one's wife and children. By the early Heian period, this pastoral view of the outlying provinces was supplanted by one rooted in the Chinese center-periphery worldview, where borderland tribes were seen as savages not blessed by the sovereign's grace. This shift can be traced to the reinforcement of the Chinese-inspired ritsuryō 律令 legal-bureaucratic state in the early days

recognize the authority of the emperor, and was not included in the household registry system. 
of the Heian period. Emperor Saga 嵯峨 (786-842; r. 809-823), a sinophile through and through, strengthened the ritsuryō system in the wake of the Kusuko Incident (Kusuko no hen 薬子の変) in 810, where the abdicated Emperor Heizei 平城 (774-824; r. 806-809) attempted to come out of retirement by staging a coup d'état against Saga with the help of his chief consort Fujiwara no Kusuko 藤原薬子 (?-810). ${ }^{3}$ As Jonathan Stockdale observes, the ritsuryo codes were more than mere words on a page; they reflected a "legal cosmology" that "rested on metaphysical assumptions about the nature of the universe and place of humanity within it." ${ }^{4}$ He further comments:
As a result, a fundamental concern in the codes of both Japan and China centers around the maintenance of social order, premised on vertical relations of hierarchy and subordination, which themselves are presented as reflections of a larger cosmic principle in which "heaven overspreads, and earth unbears." This order is further repro- duced in the archetypal Confucian relationships: those between ruler and subject, husband and wife, father and son, elder and young brother, and between friends. In this system, the correct functioning of each set of relations was portrayed as crucial not just to the proper ordering of society but to the harmonious functioning of the cosmos as well, including the proper course of the seasons and spheres. ${ }^{5}$

Concomitant with the reinforcement of the ritsuryo system was the deployment of "statecraft through writing” (monjō keikoku 文章経国) as the dominant ideology of textual production. The origins of monjō keikoku can be traced to the Dianlun lunwen 典論論 文 (Discourse on Literature), a seminal essay authored by Cao Pi 曹丕 (187-226), the first emperor of the Cao Wei 曹魏 (220-266) dynasty during China's tumultuous Three Kingdoms period (220-280). Here, he pens a line that would have a tremendous impact on the act of

\footnotetext{
3 Some contemporary Japanese scholarship now refers to this failed uprising as the "Incident by the Heizei Retired Emperor" (Heizei Daijō Tennō no hen 平城太上天皇の変) to reflect new research indicating that Heizei, not Kusuko, was the mastermind behind the plot. Nishimoto, "Kusuko no hen," p. 75

4 Stockdale, Imagining Exile, p. 93.

5 Ibid.
}

writing in the sinosphere for centuries to come: "Writing is a major enterprise in governing the state and shall flourish for eternity" (Ch. wenzhang jingguo daye buxiu zhi shengshi 文章経国大業不朽之盛事). The Dianlun lunwen was later anthologized in fascicle 52 of the Wenxuan 文選 (Selections of Refined Literature, c. 520-530), a collection of Chinese poetry and prose exemplars from the Warring States (475-225 BCE) period to the sixth century. The Wenxuan served as the vehicle that first transported monjo keikoku thought to eighth-century Japan. In short, this philosophy valorized the metaphysical properties of the written word, asserting that it possessed the power to enable proper governance, and its correct use would create a harmonious society under the emperor's rule. Sinologist Harada Ai, a scholar of the Song-dynasty (960-1279) poet Su Shi 蘇軾 (1037-1101), notes that Cao Pi's dictum motivated numerous eminent poets (or their descendants) to compile anthologies of their poetic oeuvre. ${ }^{6}$ As premodern Japanese literary scholar Gustav Heldt observes, such distinguished Japanese sinologists as Kojima Noriyuki 小島憲之 (1913-1998) initially discounted the influence of Cao Pi's thought on Nara and Heian Japanese writing, claiming that its usage was "haphazard and devoid of any ideological content." Over the past two decades, a number of researchers, including religious studies scholar Ryūichi Abé and premodern Japanese literary scholars Thomas LaMarre, Saeko Shibayama, Jason Webb, and Heldt have called this view into question, convincingly demonstrating how monjō keikoku was utilized as a practical technology for the management of state affairs. ${ }^{8}$ Although the monjo keikoku ideology had been introduced to Japan prior to Saga's ascension to the throne, it was under his reign that the ideology was used to justify the compilation of three imperially commissioned kanshi 漢詩 anthologies, the Ryōunshu 凌雲集 (Collection Soaring Above the Clouds, 814), Bunka shūreishū 文華秀麗集 (Collection of Masterpieces of Literary Flowers, 818), and Keikokushū 経国集 (Collection for Managing the State, 827). ${ }^{9}$ The Keikokushū was actually officially commissioned by Saga's successor Junna 淳和 (785-840; r

\footnotetext{
6 Harada, Soshi bungaku, p. 111

7 Heldt, The Pursuit of Harmony, p. 47.

8 See Abé, The Weaving of Mantra; LaMarre, Uncovering Heian Japan; Webb, "In Good Order"; and Shibayama, "Ōe no Masafusa."

9 Takigawa, "Keikoku no bunshō ni," p. 365
} 
$823-833)$, but the compilers were largely from Saga's poetic coterie, and thus can be viewed as an extension of Saga's poetic reign. The title accorded the third anthology clearly demonstrates the early Heian state's commitment to monjō keikoku thought.

Kükai 空海 (774-835), the putative founder of the Shingon 真言 school of Japanese esoteric (mikkyō 密 教) Buddhism, was well-versed in the classical Chinese textual tradition. Upon the appointments of court literati Ono no Minemori 小野峯守 (778-830) and Ōtomo no Kunimichi 大伴国道 $(768-828)^{10}$ to governorships in the hinterlands, Kūkai composed congratulatory epistle-poems to commemorate their new postings. These poems were included by Kūkai's disciple and amanuensis Shinzei 真済 (800-860) in the Henjō hokki seireishū 遍照発揮性霊集 (The Literary Essence of the Priest Henjō, ca. 835-840, henceforth Shōryōshū), a posthumous anthology of Kūkai's literary writings. This paper presents these poems ${ }^{11}$ in their entirety, and argues that Kükai's deft appropriation of, and allusion to, a wide variety of Chinese literary texts contributed to the Heian court's perceptions of its northeastern frontier. These poems also demonstrate that despite Kūkai's ostensible aloofness toward secular matters, his conceptualizations of writing and statecraft were thoroughly informed by the ritsuryō and monjō keikoku discourses prevalent in his era. ${ }^{12}$ Furthermore,

10 Kunimichi actually changed his family name to Tomo 伴 in 823 but will be referred to as Ōtomo throughout this study to maintain consistency and to keep his familial connection to the Ōtomo clan clear in the eyes of the reader.

11 Unless otherwise indicated, all translations are by the author. The poems presented in this essay can be found in fascicles one (Minemori) and three (Kunimichi) of the Shōryōshū. The version edited by Buddhist studies philologists Watanabe Shōkō (19071977) and Miyasaka Yūshō (1921-2011) in volume seventy-one of the NKBT was the principal source text used for this study. The commentary provided in the version edited by sinologist Imataka Makoto et al. in volume six of the KDKZ was used as a supplement.

12 On numerous occasions Kūkai expressed his desire not to be involved in secular matters and to focus on his meditative and doctrinal endeavors. One such example occurred in Daidō 大同 4 (809), just shortly after Kūkai was allowed to return to Heiankyō from Dazaifu 大宰府 and took up residence at the Takaosanji 高 雄山寺 Temple in the mountains outside the city. Saga requested that Kūkai produce Chinese calligraphic works for the court. Apparently dismayed by the imposition on his spiritual endeavors, he replied, "I, Kūkai, am a rotten branch in the forest of black-robed monks; a decomposing corpse on the Sea of the Dharma. The only things I know are carrying a bowl and staff while begging for alms, and humming in the woods and engaging in contemplation." Shōryōshū, fascicle four, Watanabe and Miyasaka, Shōryōshū, 229. Indeed, Kūkai did not respond to the
Kūkai's writings underscore how the northeastern periphery existed more as a discursive construct than a geopolitical reality.

\section{Heian Japan and its Periphery}

Peripheral regions and their inhabitants were a concern for the ancient Japanese state virtually from its inception. As the Kinai-based Yamato clans extended their influence throughout Honshu and the northern reaches of Kyushu, they inevitably clashed with the non-Yamato peoples inhabiting the fringes of their sphere of influence. Indeed, the proper title accorded to the shogun-seii taishōgun 征夷大将軍, or “generalissimo who conquers the barbarians"-emphasizes his original mandate to quell frontier rebellions. References to frontier peoples date as far back as Japan's oldest extant historical works, the Kojiki 古事記 (Records of Ancient Matters, 712) and Nihon shoki 日本書紀 (Chronicles of Japan, 720). In particular, the more sinitic Nihon shoki represents the Emishi with the sinographs 夷 or 蝦夷. The character 夷 underscores the continental influence on the early Japanese worldview, as it was also used by the Chinese as a label for the dongyi 東夷, the non-Han tribes to the east. The same histories named the non-Yamato peoples residing along the southern boundaries of the Japanese area of control as the Hayato 隼人. Historian Sakaue Yasutoshi notes that the Hayato were fully incorporated into the Japanese household registry and agricultural land distribution system by the early $80 o$, in effect making them Japanese subjects on an equal footing with the Yamato Japanese. ${ }^{13}$ Despite the court's success in pacifying its southern borderlands, the Emishi were a constant annoyance. Entries in the Nihon shoki present an unstable relationship between the Yamato state and its northern neighbors: the Emishi

emperor's request until two months after receiving the folding screens, as he was unwilling to interrupt a meditative retreat to accommodate Saga's request. Abé observes, "Kūkai's behavior, suggestive of lack of respect, or even disloyalty, to the throne, seems to have invited criticism from his fellow courtiers" (Abé, The Weaving of Mantra, p. 308). Rhetorical declarations aside, Kūkai was actually actively involved in court affairs, as he served in the Ministry of the Center (Nakatsukasashō 中務省) at Saga's behest in 819, supervised the repairs to the Mannoike 満濃池 reservoir in his native Sanuki 讃岐in 821, and established Japan's first private school, the Shugeishuchiin 綜芸種智院 (School of Arts and Sciences) in 828.

13 Sakaue, Ritsuryō kokka, p. 104 
are depicted as either docile bearers of tribute or rebels requiring military pacification. In any case, relations with the Emishi are narrated in solely military or diplomatic terms. Official histories are replete with instances of unfortunate encounters with borderland clans and decades of military pacification campaigns that took up the better part of the eighth century. Yet as historian Karl Friday observes:

[D] espite their prominent place in the court's historiography, the wars themselves accomplished little. The government declared victory in 811 , but with the better part of Mutsu and Dewa under no firmer court control than it had been before 774. Where the state's grasp over the northeast broadened or deepened during the war era, it did so primarily because of the continuation of older techniques for extending Yamato influence in the region, techniques that persisted for decades after the subjugation campaigns officially ended. In point of fact, most Japanese scholarship on conditions and events in the northeast during the Nara (710-94) and Heian (794-1185) periods supports this conclusion, without voicing it directly. ${ }^{14}$

Friday's analysis demonstrates that the northeastern frontier cannot be viewed strictly in terms of territorial gains and extent of actual state control. Equally as important to any discussion on Mutsu and Dewa 出羽 is how these territories were perceived textually. Despite the court's unilateral declaration of victory in 811 , Kūkai's description of the borderlands in his epistle-poems to Minemori in 815 and Kunimichi in 825 indicate that the Emishi did not share the court's appraisal of the situation.

On the dawn of the ninth century, aristocratic policymakers viewed the frontier problem in both militaristic and ideological terms. In particular, the year 797 is crucial to understanding the Heian court's relationship with its frontier and Kūkai's place within this political and intellectual milieu. According to the Nihon $k \bar{o} k i$ 日本後紀 (Later Chronicles of Japan, 840), another official history, court scholar Sugano no Mamichi 菅野真道 (741-814) reported to Emperor Kanmu 桓武 (735-806; r. 781-806) that the first half of the Shoku Nihongi 続日本紀 (Continued Chronicles of Japan, 797)

14 Friday, "Pushing Beyond the Pale," p. 2. had been completed. ${ }^{15}$ More importantly, the report lauds Kanmu for his enlightened governance that extends beyond the Yamato ethnocultural sphere, reaching such distant regions as the mixed Korean-Tungusic kingdom of Bohai 渤海 (located in present-day northeastern China, North Korea, and the southern portion of the Russian Far East) and the Emishi territories to the northeast. ${ }^{16}$ The juxtaposition of these referencesnamely, the partial completion of the Shoku Nihongi and the pacification of the northeastern frontier and its inhabitants - amply demonstrates the power of the written word as a technology of statecraft. Like its continental cultural benefactor, early Heian Japan could claim nationhood because it produced written histories, tamed its frontier barbarians, and then textually incorporated them into these histories. This was just a few short years after Kükai's brief stint at the State Academy (Daigakuryō 大学寮), where he had been exposed to a curriculum saturated with monjō keikoku ideology.

Continental castaways were also not spared the Emishi's wrath. The Shoku Nihongi records an incident in 727 where a tributary mission from Bohai came ashore in Emishi territory. Only eight of the twentyfour members managed to survive the Emishi slaughter and safely reach the Yamato court in the south. ${ }^{17}$ Another Bohai delegation that drifted into Emishi territory in 786 fared better: this time, only twelve people from the sixty-five member delegation were killed. ${ }^{18}$ Another entry from the Nihon kōki reports a third Bohai embassy in 795 also had the misfortune of unintentionally trespassing on Emishi land, but does not specify the number of casualties, only that "the people were scattered and goods were lost."19 These three Bohai missions all had the same result: considerable loss of lives and property. The 786 and 795 incidents are particularly noteworthy because they occurred despite the large-scale military campaigns by government forces in the 770 s and 780 s where armies of tens of thousands of troops were raised and

\footnotetext{
15 Nihon kōki, Enryaku 延暦 16 (797).2.13.

16 Nihon kōki, Enryaku 16.2.13.

17 Shoku Nihongi, Jinki 神亀 4 (727).12.29

18 Shoku Nihongi, Enryaku 5 (786).9.18.

19 Nihon kōki, Enryaku 14 (795).11.3. This entry is preserved in the Ruijū kokushi 類聚国史 (Classified National History of Japan, 892), a compendium and reconstruction of prior official histories edited by Sugawara no Michizane 菅原道真 (845-903) at the behest of Emperor Uda 宇多 (867-931; r. 887-897). Ruijū kokushi, 193 Bokkai 渤海, Enryaku 14 (795).11.3.
} 
dispatched to Mutsu. Friday notes that the numerical, technological, and strategic superiority of the Japanese forces did not fare well against the hit-and-run guerilla tactics of the Emishi bands. ${ }^{20}$ Thus, in reality, the conquered frontier proclaimed in the 797 Nihon kōki entry represented more of an optimistic Heiankyō ideal of the northeast than the actual situation on the ground.

\section{Enter the Poet-Governor: Kūkai's Epistle to Ono no Minemori}

Kükai witnessed the aftermath of these events unfold in the capital. He was personally affected by the Heian court's policies regarding the renegade region, as over a ten-year period two people close to him were appointed its governor: the aforementioned Ono no Minemori and Ōtomo no Kunimichi. Both were seemingly unlikely choices due to their lack of experience as military commanders or outlying provincial governors. On the eve of their respective departures to their new postings, Kükai presented them with congratulatory epistle-poems written in literary Chinese. In these texts, Kükai presents a new ideal for the frontier administrator-a literati-bureaucrat who is also an accomplished poet and will serve as a cultural emissary that brings the ideology of monjo keikoku to the benighted hinterlands.

Minemori was appointed governor of Mutsu Province in 815 . He was known as one of Saga's court poets and for his involvement with the compilation of the Ryounsh $\bar{u}$, the first imperially commissioned anthology of Chinese poetry. In addition to having thirteen of his compositions included in the ninety-one poem collection (he was tied with Kaya no Toyotoshi 賀陽 豊年 (751-815) and outdone only by Saga, who had twenty-two entries), Minemori also had the honor of penning the preface. His prelude is nothing less than a testament to the monjo keikoku ideology, as he opens by quoting Cao Pi's axiom from the Dianlun lunwen. Although personally unexperienced in military or frontier administrative affairs, he did have the proper lineage for the assignment, as he was the third son of Ono no Nagami 小野永見 (d.u.), a previous Vice-Generalissimo who Pacifies the Barbarians (seii fukushōgun 征夷副将軍) and Vice Governor of Mutsu (Mutsu no

20 Friday, "Beyond the Pale," pp. 15-16. suke 陸奥介). Yet, Minemori's lack of experience was superseded by his status as a poet of the first rank, making him exactly the kind of person needed to bring the emperor's civilizing force to the frontier.

Kūkai's sinocentric orientation is evident from the beginning of his epistle. ${ }^{21} \mathrm{He}$ opens with the greeting:

戎狄難馴、邊笳易感、自古有、今何无。公抱大 廈之材、出鏳犲狼之境。堂中久關定省之養、魏 關遠阻龍顔之謁。雖云天理合歡然、人情豈无感 歎。貧道與君遠相知、山河雲水何能阻。白雲之 人、天邊之吏、何日无念。聊抽拙歌、以充邊霧 之解頣。

The Rong and Di are difficult to tame, so the sound of the reed flute in the frontier stirs the heart. It has been this way since ancient times, why would it have changed now? You will take your immense talents and pacify the frontier of wild dogs and wolves. For quite some time you will not perform the customary courtesies to your parents at home and your distance from the court will prevent you from having an audience with the emperor. In principle your appointment is worthy of congratulations, yet who with feelings would not lament? You and I have known each other for a long time; how can the mountains, clouds, and waters keep us apart? Though I am a man in the white clouds and you a bureaucrat on earth, will there be a day when we do not think of each other? I dash off the following poem for you in the hope it dispels the frontier fog.

The Emishi are given the uncomplimentary appellations of Rong 戎 and Di 狄, references to two of the non-Han barbarian tribes that traditionally inhabited the regions north of the Chinese sphere of influence. Labelling the Emishi as such serves to transpose the Chinese worldview onto the early Heian Japanese state, where the Heian capital becomes the "Middle Kingdom" and the periphery is relegated to the status of barbarian terri-

21 This text is in fascicle one of the Shōryōshū under the title Ya Rikushū ni okuru uta jo o awasetari zōgen 贈野陸州并序雑言 (Poem on the Occasion of Ono no Minemori's Departure to Mutsu, Preface Attached, Unregulated Verse). Watanabe and Miyasaka, Shōryōshū, pp. 164-67. 
tories. This is an attempt by Kūkai to textually shape the Japanese state along Chinese lines, complete with its own "difficult to tame" barbarians who have yet to be brought into the fold of Confucian rationalism, and describing them as "wild dogs and wolves" serves to further dehumanize them in the eyes of his reader. His mention of the "reed flute" calls further attention to the alien nature of the Emishi, a reference likely inspired by a phrase in the Houhanshu 後漢書 (Book of the Later Han, ca. fifth century) depicting "barbarian reed flutes stirring the frontier horses to bray" (Ch. hujia dongxi bianma ming 胡笳動合邊馬鳴). In Chinese diction, the "barbarian reed flute" (Ch. hujia 胡笳) was associated with the tribes to the north of the Han sphere of influence, thus perfectly corresponding to the Emishi insofar as cardinal direction. A crude instrument made from coiled reeds, its very appearance was likely intended to evoke images of untamed wilderness. Also, the sound produced by the flute was considered plaintive and melancholy, adding an additional layer of forlornness to the landscape. Reed flutes as emblems of the frontier were well-established in Tang poetry, and appeared in a subgenre of Tang poetry that later came to be known as "frontier poems" (Ch. biansaishi 辺塞 詩). ${ }^{22}$

While Kūkai's poem uses slightly different diction than the Houhanshu-he refers to the flute as a "frontier reed flute" (henka 邊笳) as opposed to "barbarian reed flute" - one can reasonably infer that Kūkai was

22 One such example is the "Poem on Liangzhou" (Ch. Liangzhoushi 涼州詩) by the early Tang poet Wang Han 王翰 (687-726):

\section{秦中花鳥已應闌 \\ 塞外風沙猶自寒 \\ 夜聽胡笳折楊柳 \\ 敎人意氣憶長安}

Though the blossoms and birds in Qin [Shaanxi, location of Chang'an] are surely at their peak

The sandstorms outside the frontier fortress are still ever so cold

At night, hearing the song of the broken willow bough on the barbarian reed flute

Heart aroused, one cannot help but long for Chang'an

Liangzhou is the former name for present-day Wuwei City in Gansu Province, and during the Tang dynasty was one of the frontier outposts of Han Chinese civilization. The poem by Wang Han above is presented as it appears in fascicle 156 of the Quan Tangshi 全唐詩 (Complete Tang Poems), a forty-nine-thousandpoem compendium of Tang poetry compiled in the eighteenth century. Peng Dingqiu, Quan Tangshi, p. 1605 inspired by the imagery presented in the Houhanshu. As the Houhanshu was a core text in the early Heian Chinese classics curriculum, Minemori probably would have understood the allusion.

These salutatory remarks serve as a preface to the poem itself. From the opening stanzas, Kükai narrates the extreme difficulties previous emperors, generals, and governors faced in dealing with Mutsu Province:

\section{日本麗城三百州 \\ 就中陸奥最難柔 \\ 天皇赫怒幾按劒 \\ 相將幄中争馳謀 \\ 往帝伐 今上憂 \\ 時々牧守不能劉 \\ 自古將軍悉啾々}

In the three hundred islands that comprise the beautiful land of Japan,

The province of Mutsu has been the most difficult to tame.

On numerous occasions the emperor has gripped his sword in fury,

Ministers and generals argue in battlefield tents and hatch strategy,

Previous emperors have taken up the battle cry, and the current emperor laments.

Previous governors have been unable to vanquish the barbarians

From ancient times, generals have cried in agony.

Kükai's opening declaration, "In the three hundred islands that comprise the beautiful land of Japan / The province of Mutsu has been the most difficult to tame," underscores the belief held by the Heian state that the region was unequivocally theirs. In addition to textually claiming the contested region, Kükai provides a thumbnail sketch of earlier engagements with their northeastern frontier. Prior attempts to subdue the region by force were unsuccessful, with previous emperors, governors, and generals returning to the capital in defeat.

The historical context of Japanese encounters with the northeastern frontier is followed by several lines that provide an overview of the culture, customs, and habits of the Emishi: 
毛人羽人接境界

猛虎犲狼處處鳩

老鴊目 猪鹿装

䯽中插著骨毒箭

手上每執刀與矛

不田不衣逐麻鹿

靡晦靡明山谷遊

The Hairy People ${ }^{23}$ and Feathered People threaten our borders,

Forming packs like ferocious tigers, wild dogs, and wolves.

With eyes like an old crow, they don skins made of boar and deer,

Poisoned arrows made of bone pierce their hair knots,

Swords and spears are ever present in their hands.

They do not cultivate rice fields nor do they weave clothes, they hunt for deer.

Day and night, they wander around the mountains and valleys.

Once again, these frontier "barbarians" are depicted in rather deprecatory terms. Kūkai highlights differences in physical appearance and mode of dress: the Emishi are a "hairy" and "feathered" people, and unlike capital aristocrats attired in the proper Chinese-inspired robes, they "don skins made of boar and deer." The "poisoned arrows" doubling as hairpieces and the weapons "ever present in their hands" impart a sense of lethal danger. Indeed, the Emishi are portrayed as being nothing but animals guided by their basest instincts that form packs "like ferocious tigers, wild dogs, and wolves." The use of the sinograph 鳩 to represent the verb "gather" adds a visual element to the poem by amplifying the animalistic nature of the Emishi through his suggestion that they flock like wild pigeons in the sky. Kükai's most

23 References to the Hairy People and Feathered People (Ch. yuren 羽人) appear in the Shanhaijing 山海経 (The Canon of Mountains and Seas, date uncertain), an Early Han mythic geography. Imataka et al., Henjō hokki shōryōshū, p. 185.

The material in this extensive collection is considered the source of many myths and legends that appeared in later ages. Hu

Ying writes, "A fantastic map of a largely imagined universe, it is a collection of strange flora and fauna, gods and goblins, and humans of every imaginable shape." Hu, "Records of Anomalies," pp. 544-45. damning judgment, however, is that " $\mathrm{t}$ ]hey do not cultivate rice fields nor do they weave clothes, they hunt for deer." Here, he makes the sweeping assertion that the Emishi have rejected the foundations of East Asian agricultural communalism and social organization. ${ }^{24}$ In his estimation, the Emishi are uncivilized because rather than engage in wet-rice cultivation - a mode of agricultural production considered to require coordinated physical labor and harmonious social relationships - they opt to lead a subsistence lifestyle centered on hunting and gathering. Furthermore, their unwillingness to weave clothing is viewed as just additional evidence of their uncivilized nature. The Emishi satisfy their basic food and clothing needs through roaming the mountains and valleys hunting for deer.

This seven-line description of Emishi customs leads into another stanza describing the conflicts between the aboriginal Emishi and Japanese colonists:

\section{羅刹流 非人儔 \\ 時々來往人村里 \\ 繁食千萬人與牛 \\ 走馬弄刀如電撃 \\ 彎弓飛箭誰敢囚 \\ 苦哉邊人每被毒 \\ 歲々年々常喫愁}

They are like the man-eating Raksasa devils, they are not human

They frequently come to our settlements,

Where countless people and oxen are massacred and eaten

Their galloping horses and brandished swords are like flashes of lightning 
When they pull their bowstrings and let loose their arrows, people get hit

How terrible it is! The locals are always getting injured

And suffer year in and year out.

Kükai likens the Emishi to the "man-eating Raksasa devils" of Buddhist lore, claiming they have engaged in acts of cannibalism against the Japanese. Frequent incursions by the Emishi into Japanese settlements have apparently resulted in tragedies where "countless people and oxen are massacred and eaten." Kūkai's description of the Emishi, and his lament over the fate visited upon the Japanese colonists serves as a prelude to Minemori's appointment as Mutsu's new provincial governor:

\section{我皇爲世出能鑒 \\ 亦咨焉刃局 \\ 千人萬人擧不應 \\ 唯君一箇帝心抽 \\ 山河氣五百賢 \\ 允武允文得自天 \\ 九流三略肚裏吞}

For the sake of the realm, our emperor set out and carefully observed the present situation..$^{25}$

He consulted both soldiers and officers. ${ }^{26}$

Although tens of thousands of soldiers volunteered for the governorship, none were suitable.

25 Watanabe and Miyasaka interpret 鑒 as "to examine various precedents" (rei ni terashite yoku kangaete 例に照らしてよく考えて). Watanabe and Miyasaka, Shōryōshū, p. 166.

26 The precise meaning of this line is unclear. The commentaries in the NKBT and KDKZ editions of the Shöryōshü both suggest that a character is probably missing from this line since the final sinograph 局 does not fit the rhyme scheme of the poem. Imataka (KDKZ) proposes that 刃局 refers to the "offices responsible for military affairs" (gunji tantō no yakusho 軍事担当の役所). Imataka et al., Henjō hokki shōryōshū, p. 185. He renders this line as mata kore jinkyoku ni hakaru 亦た焉刃局に咨る and translates it as kono koto o gunmu no yakusho ni sōdan saretaこの事を軍務の役所に相 談された ("The emperor consulted the military affairs bureaus on this matter"). Imataka et al., Henjō hokki shōryōshū, p. 168. Watanabe and Miyasaka (NKBT) provide an alternative interpretation, glossing this line as nageite yaiba osamu 咨いて刃局む ("Sighing, he returned his sword to its scabbard"). Watanabe and Miyasaka, Shōryōshū, p. 166. I am indebted to the anonymous reviewer, who pointed out that 刃局 can be treated as a compound meaning the "officers and soldiers."
Only you were chosen by the emperor.

With wisdom tall as a mountain and deep as a river,

You are a genius that appears once every five hundred years.

Your talent in military and literary arts was bestowed by the heavens.

Your belly contains the teachings of the Nine Schools and the Three Strategies.

Continued instability in the northern reaches required a new strategy. As reigning emperor, Saga is depicted as a paragon of Confucian virtue, "carefully observing the situation" and wisely concluding that mere application of brute force would not resolve the situation. Ultimately, the combined strength of "tens of thousands of soldiers" could not match the wit and talent of one learned poet. Although Minemori's biography does not indicate any actual military or combat experience, Kūkai lauds him as one equally versed in the martial and belletristic arts. While it is tempting to view this as an early Heian manifestation of the medieval warrior ethos of bunbu ryōdō 文武両道, where proficiency in warcraft and letters were valorized as the warrior's creed, here Kükai turns the concept on its head. The idealized Japanese swordsman, such as Taira no Atsumori 平敦盛 (1169-1184) and Taira no Tadanori 平忠度 (1144-1184) of Heike monogatari 平家物語 (Tale of the Heike, ca. thirteenth century) fame, were soldiers first and poets second. Minemori, on the other hand, is first and foremost a man of letters who also happens to be conversant in military tactics. Kükai's invocation of the "Nine Schools" can be interpreted literally or figuratively - either as a generic designation for the nine traditions of classical Chinese thought, or as a kaleidoscopic term encompassing the entire landscape of sinitic learning. Concomitant with Kūkai's exhortation of Minemori's erudition is an implicit assertion that the Emishi are uncivilized precisely because they lack this body of learning. This is followed by a specific description of how Minemori will bring civilization to the frontier:

鵬翼一搏睨此境
毛人面縛側城邊
凶兵藴庫待治鑄
智劍滿胸幾許千
不戦不征自無敵




\section{或男或女保天年}

With one flap of your mighty roc wings, you survey the terrain below.

The Hairy People are rounded up and brought to the castle.

Their lethal weapons are stored away and await being melted and reforged.

How many thousands of wisdom swords fill your bosom?

No need to fight, no need to conquer, you are naturally without enemies.

Men and women are now able to live out their heaven-bestowed life spans.

Commentaries on Kūkai's poetry identify "mighty roc wings" as an allusion to "Enjoyment of Untroubled Ease" (Ch. xiaoyaoyou 逍遥遊), one of the "inner chapters" (Ch. neibian 内篇) of the Zhuangzi 莊子 (ca. third century BCE). In the universe of the Zhuangzi, the roc (Ch. peng 鵬) is a massive bird whose wings appear to cover the entire sky upon taking flight. The seas below are moved by powerful flaps of the bird above. Kükai expands upon this image to depict Minemori as a roc bearing the emperor's virtue, fanning the wings of enlightened governance to bring the unruly territories below under its sway. The use of the sinograph 境 to refer to Mutsu allows for a certain degree of interpretive ambiguity, as it can mean a demarcated region, boundary, or frontier. The discrepancy between Heiankyō geopolitical dogma and the reality in the contested region make all three renderings equally tenable. Once Minemori swoops into Mutsu Province, the Hairy People will be forced to capitulate and surrender their weapons. Kūkai's declaration that "their lethal weapons are stored away and await being melted and reforged" suggests that their instruments of war will be recast into useful agricultural implements. In an ironic twist, Kūkai acknowledges the potential for weapons to be useful in the proper hands, as Minemori's vast learning is likened to a sword. Nevertheless, in the following lines Kükai reminds Minemori that scholarship, not the sword, will carry the day:

\section{昔聞娞帝于儛術}

今見野公略无疋
I heard that long ago Emperor Shun mastered the art of dancing with his shield,

Now I see your tactics are in a league of their own.

The tale of the fabled Shun placating his enemies by performing a shield dance inside their encampment is well established in traditional Chinese historiography. Here, however, another narrative thread provides an additional dimension to his verse. In the Baihutongyi 白虎通義 (Virtuous Discussions of the White Tiger Hall, 79), a first-century commentary on the classics authored by historian Ban Gu 班固 (32-92), the following juxtaposition between barbarian tribes and dances can be seen:

東夷之樂持矛舞助時生也。南夷之樂持羽舞助時 養也。西夷之樂持戟舞助時笅也。北夷之樂持干 舞助時藏也。誰制夷狄之樂。以為先聖王也。先 王惟行道德和調陰陽覆被夷狄故夷狄安樂來朝中 國於是作樂樂之。

In the music of the Eastern Barbarians, they dance holding spears, and aid in the creation [of music]. In the music of the Southern Barbarians, they dance holding feathers, and they aid in the development [of music]. In the music of the Western Barbarians, they dance holding halberds, and they aid in the paring down [of music]. In the music of the Northern Barbarians, they dance holding shields, and they aid in the storage [of music]. Who composes the barbarians' music? It was none other than the sage-kings of old. The kings of old practiced only virtue, they harmonized yin and yang. Their virtues engulfed the barbarians, so the barbarians became peaceful. They paid tribute to the Middle Kingdom, so music was produced for their enjoyment. ${ }^{27}$

Kūkai deftly blends the two narratives by situating Shun's shield dance within the context of pacifying barbarians without resorting to brute force. Shun defeated his enemies by performing a shield dance in their midst; Minemori will bring peace and harmony to the barbarians of the north in a similar manner.

Aside from the poisoned arrows and man-eating

27 Ban Gu, Baihutongyi, fascicle two. 
barbarians, Minemori's posting in the far reaches of the Japanese periphery had another major downside. While serving his tour of duty in the wilds of Tōhoku, he would be denied the privilege of serving the emperor in the capital. Kūkai warns his friend about what awaits him:

\section{京邑梅花先春開 \\ 京城楊柳茂春日 \\ 邊城遲暖無春藥 \\ 邊壘早冬无茂實}

In the capital the plum blossoms herald the arrival of spring,

The willows at the imperial palace flourish under the spring sun.

Yet at your provincial citadel warmth arrives late and there are no spring blossoms

Winter comes early to your frontier fortress and the branches bear no fruit.

Because Mutsu Province was indeed located at a higher latitude than the Kinai plain, in fact spring did arrive later and winter sooner. Yet Kūkai is not concerned with such matters of cartography and climatology. Rather, in his sinitic worldview, the radiance and benevolence of the Japanese emperor, and thus the early Heian state, radiate outward from its center in Heiankyō. Also, under the ideology of monjō keikoku, properly deployed language has the power to regulate the state, and by extension, the seasons. The northeastern fringes of Japanese civilization were bereft of the emperor's munificence, thus resulting in the delayed arrival of the warm season. Here, Kūkai appropriates the rhetoric and diction of the aforementioned Tang frontier poems, juxtaposing the luxuriant warmth of the capital with the barren cold of the periphery.

In the end, Kūkai admonishes Minemori to not despair over his assignment, as he will certainly reap the rewards of loyal service:
Though the emperor may be in the heavens, his ears are always close to the ground

All the more will the cry of the crane be heard from the deepest marsh!

Do not lament your extended residence in the land of wind and dust,

Our emperor will surely make you the lord of ten thousand households.

This conclusion represents a departure from the tone evident in continental frontier poems, where the poet generally laments their posting far removed from the capital. The borderlands of Han civilization are depicted in bleak, foreboding terms, and being posted to these regions is akin to exile or banishment. Kūkai reminds Minemori, however, that his term of service in Mutsu will be a limited one, and he will be rewarded by the emperor upon his return.

Minemoris tour of duty in the frontier appears to have been successful. In 817 , he reported that the Emishi "surrendered barbarian" (fush $\bar{u}$ 俘囚) Kimikobe no Tohashiko 吉彌侯部等波醜 (d.u.) had capitulated after years on the run from the Japanese authorities. Saga praised Minemori's capture of Kimikobe, stating "This bandit has escaped punishment for far too long. Minemori has tamed his wild heart and taught him to submit to the will of the imperial court. Such measures at pacification are truly gratifying." ${ }^{28}$ Kūkai's final words to Minemori were apparently prophetic-upon completing his assignment in Mutsu, he served as governor of Ömi 近江, where he implemented a number of relief measures to alleviate a drought-induced famine in the capital. Ultimately, his bureaucratic accomplishments resulted in a promotion to councilor (sangi 参 議) and senior assistant governor general of Dazaifu (Dazaifu daini 大宰府大武) in 822. The following year, Minemori proposed what scholars would later consider his signature policy initiative - the experimental implementation of agricultural land nationalization (kueiden 公営田) in Kyushu to bolster sagging tax revenues. ${ }^{29}$

高天雖高聽必卑

況乎鶴響九泉出

莫愁久住風塵裏

聖主必封萬戸秩

28 Nihon kōki, Kōnin 弘仁 8 (817).7.5. This entry is also preserved in
the Ruijū kokushi. Ruijū kokushi, 190 Fushū 俘囚, Kōnin 8.7.5. 29 Gotō, "Ono no Minemori shōron," p. 17. 


\section{Kūkai's Epistle-Poem to Kunimichi}

Despite Minemori's success, problems persisted. Ten years later, in 825 , Saga's successor Junna decided to dispatch another official to manage the troubled region. Chosen this time was Ōtomo no Kunimichi, an aristocrat with a checkered past due to his affiliation with the Otomo clan. Kunimichi was no stranger to the periphery of the Heian state, as he was exiled to Sado Island at the age of seven after his father Ōtomo no Tsuguhito 大伴継人 $(?-785)$ was executed for his involvement in the assassination of Fujiwara no Tanetsugu 藤原種継 (737-785) at Nagaokakyō. Kunimichi remained on the island until he was pardoned in 803 (his father was posthumously pardoned and had his rank restored in 806). Although his eighteen-year exile removed him from the mainstream of Heiankyō politics for what should have been the formative years of his career, he distinguished himself upon his return to the capital and quickly rose through the ranks. He was also intimately familiar with the Mutsu region, having previously served as its junior provincial inspector general (shōen 少掾) in 811 and provisional vice governor (gonnosuke 権介) in 812. As a seasoned veteran of the provinces - both personally and professionally-he was well prepared for his new assignment as regional inspector for the northeastern frontier (rikufu azechi 陸府按察使). At least on paper, Kunimichi's posting could be considered higher than Minemori's because as regional inspector he had oversight over both Mutsu and Dewa provinces. ${ }^{30}$

Like Minemori before him, Kunimichi embodied the essence of the scholar-bureaucrat. While his predecessor was deeply steeped in the Chinese poetic tradition, Kunimichi came from a line of distinguished poets who also wrote in Japanese. Certainly, the Ōtomo are well known in the history of Japanese literature, producing such outstanding poets as Tabito 旅人 (665-731) and his son Yakamochi 家持 (ca. 718-785). Tabito's mater- nal half-sister Ōtomo no Sakanoue no Iratsume 大伴 坂上郎女 (ca. 695-active until 750) had over seventy poems included in the Man'yōshü. Once again, Kūkai presented the newly appointed governor with a congratulatory epistle-poem: ${ }^{31}$

夫膚寸無心南北。遇風則飛。順之德也。人臣無 意東西。銜命則馳。忠之至也。最爾毛夷。迫居 艮垂。犲心蜂性。歷代爲梗矣。昔景行皇帝。撫 運之日。東夷未賓。日本武尊。率左右將軍。武 彦武日命等。征之。毛人面縛之。日命則君之先 也。

The clouds have no desire to go north or south, but should they encounter the wind, they fly off - this is the virtue of obedience. The emperor's retainers have no desire to go east or west, they go where they are ordered - this is the pinnacle of loyalty. The petty Hairy Barbarians have been closing in on our northeastern frontier and making a nuisance of themselves for generations with their wolf-hearts and bee-like natures. Long ago, when Emperor Keiko $\bar{o}^{32}$ pacified the nation, the Eastern Barbarians had yet to submit to his authority. Yamato Takeru led the generals Takehiko no Mikoto and Takehi no Mikoto into battle to subjugate them, and the Hairy Barbarians surrendered. Takehi no Mikoto is none other than your ancestor.

Kūkai's missive to Kunimichi shares a number of rhetorical similarities with the earlier one presented to Minemori. Once again, the Emishi are accorded the uncomplimentary appellation of "Hairy Barbarians," and this time, they are depicted as "petty." Comparing their character to wolves and bees immediately con-

31 This text is in fascicle three of the Shöryōshū under the title Han anzatsu heishōshi ga Rikufu ni okuru uta 贈伴按察平章事赴陸 府歌并序 (Poem Sent to Councilor Ōtomo no Kunimichi on the Occasion of His Appointment to the Regional Inspectorship of Mutsu, Preface Attached). Watanabe and Miyasaka, Shōryōshū, pp. 218-22.

32 Emperor Keikō 景行 (d.u., traditionally late first to early second century), the twelfth emperor, is held in semi-legendary status but there is a lack of actual documentation about his reign. He is traditionally credited with ordering his son, Yamato Takeru 日本武 尊 (see below) to lead an expedition into the northeast to pacify the Emishi. Farris, Heavenly Warriors, p. 84 
jures images of aggressive creatures governed solely by instinct and functioning solely within a pack or hive mentality. They are the exact opposite of Japanese court officials, who are viewed as exemplars of the Confucian virtues of obedience and loyalty. Kükai also claims that Kunimichi is descended from a general who served the semi-mythical Yamato Takeru 日本武尊, thus situating him as the progeny of a military hero.

History has amply demonstrated that Japanese victory in the troubled region was not fated to endure. Kükai elaborates on this point, mentioning that another of Kunimichi's esteemed forefathers was dispatched into the wilderness to disabuse the inhabitants of their mistaken belief that they were not part of the Japanese state:

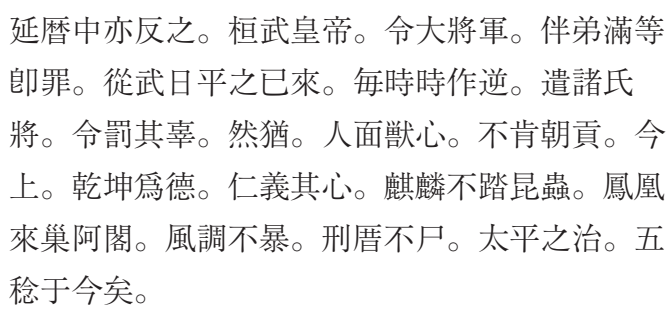

During the Enryaku years, the Hairy Barbarians rose up again. Emperor Kanmu ordered General Tomo no Otomitsu to immediately subjugate them. Since the time of Takehi's pacification, there have been frequent rebellions. Various ministers and generals were sent and ordered to punish them for their transgressions. However, although they have the faces of humans, they have the hearts of beasts and refuse to offer tribute to the emperor. The present emperor displays the virtues of heaven and earth, directing his heart toward benevolence and righteousness. The [mythical chimera] kirin does not trample on insects, and the phoenix makes the grand palace its nest. The winds are calm and do not flare up. Although the Penal Law is on the books, it is never used. It has been five years since Junna ascended the throne, and peace has prevailed throughout the land.

Kūkai simultaneously frames the problem in militaristic and legalistic terms. Such diction as "rose up," "rebellions," "subjugate," and "pacify" describe tensions between the Japanese and Emishi as antagonistic and combative. Yet the dispatch of "ministers" to "pun- ish" the Emishi for their "transgressions" suggests that Heiankyō policy toward the Emishi was also being viewed as a legal matter that could be addressed via civil government. In effect, as subjects of the Heian state the Emishi were bound by its laws, and the Japanese were justified in dispatching punitive forces to reassert their legal right to govern the region.

Yet the Heian court's sole reliance on military force and legalistic reasoning proved insufficient. Kükai provides a third alternative: the enlightened governance of the Confucian philosopher-king. Junna follows in Saga's example and exemplifies the virtues of benevolence and righteousness. Kūkai also observes that while a written Penal Code is in effect, Junna's righteous rule has made its implementation unnecessary.

Nevertheless, the situation in Japan's northeastern fringe required action. Once again, Kükai turned to Chinese history for a solution. Events occurring during the reign of two mythical Chinese emperors are used to further justify Japanese actions in Emishi territory:

\section{夫无爲之世。致有苗之伐。垂拱之時。有溷鹿之 戰。時已澆季。仁義之郷。返爲胡越。此屬。神 光怪氣發東。地震流星起西。皇帝納隍軫慮。郎 欲遣文翁孫子。鎭押東夷。}

During the reign of Emperor Shun, a time when the realm ruled itself, he ordered the invasion of the Kingdom of Youmiao; during the reign of the Yellow Emperor, and the sleeves of the emperor's ceremonial robes flowed free, ${ }^{33}$ there was the battle at Zhoulu. In this time of moral decay, realms of benevolence and righteousness will become

33 "Sleeves flowing free and hands folded" (Ch. chuigong 垂拱) is an abbreviated form of chuiyi gongshou 垂衣拱手, a cliché found throughout the Chinese classics that refers to a self-governing realm under a benevolent emperor. Since righteousness prevails throughout the land, the monarch does not need to doff his court robes for military attire. Both the NKBT and KDKZ annotators point to a line in the Shujing (refer to explanation below) as the locus classicus: "The sleeves of the emperor's robes draped down, he folded his hands, and order prevailed throughout the realm" (Ch. chuiyi er tianxia zhi 垂拱而天下治). Imataka et al. observe that while the Shujing passage originally referred to King Wu of Zhou 周武王 (?-1043 BCE; r. 1046-1043 BCE), here Kunkai uses the line to describe the virtues of the Yellow Emperor. Watanabe and Miyasaka, Shōryōshū, p. 220; Imataka et al., Henjō hokki shōryōshū, p. 263. 
barbaric like the lands of $\mathrm{Hu}$ and Yue. ${ }^{34}$ Recently, there have been mysterious lights and strange phenomena in the east, and earthquakes and shooting stars in the west. The emperor takes the plight of the villages into account and wants to send you to conquer the Eastern Barbarians, since you are just like Wen Weng ${ }^{35}$ or Sun Zi.

According to the Shujing 書経 (Book of Documents, date unknown, traditionally attributed to Confucius) the Youmiao 有苗 were a non-Han tribal people living on the periphery of the Chinese state. ${ }^{36}$ Youmiao tribes traditionally resided in the southern mountains of modern-day China, and are related to the Hmong of northern Vietnam and Cambodia. Zhoulu 波鹿 was the site of the famous battle between the Yellow Emperor and Chiyou 虫尤, the leader of the Nine Li (Ch. Jiuli 九黎), another non-Han tribal league. In both instances, the Han sovereign is depicted as an exemplary leader capable of ruling without effort. Traditional Chinese political philosophy valorizes the concept of “effortless governance" (Ch. wuwei 無為), a leadership style possible in realms where morality and virtue prevail. Despite the tranquility in the Han sphere of influence, the presence of frontier tribes that would not accede to Chinese authority were perceived as a threat, thus justifying preemptive action. Kūkai draws parallels between continental precedent and the ensuing crisis in Mutsu Province.

A sense of urgency is also present in Kūkai's epistle to Kunimichi. Reports of "mysterious lights and strange phenomena in the east" and "earthquakes and shooting stars in the west" suggest anxiety over the court's handling of frontier affairs; after all, if imperial virtues were properly maintained, such phenomena should not occur. Sinologist Nakatani Masamitsu observes that Kükai borrowed the aforementioned diction and associated imagery directly from two continental classical histories, the Hanshu 漢書 (Book of Han, 111) and the

\footnotetext{
$34 \mathrm{Hu}$ 胡 and Yue 越 are generic appellations referring to the non-Han peoples on the periphery of the Chinese sphere of influence. "Hu" was used for those in the north, and "Yue" the south. Imataka et al., Henjō hokki shōryōshū, p. 263.

35 Wen Weng 文翁 (187-110 BCE) was the regional magistrate (Ch. junshou 群守) of Shu 蜀 (present-day Sichuan Province) and reputably fond of scholarship. He devoted himself to "civilizing" the Shu, who in turn developed an interest in learning as a result. Watanabe and Miyasaka, Shōryōshū, p. 220

36 Imataka et al., Henjō hokki shōryōshū, p. 263.
}

Guoyu 国語 (Discourses of the States, ca. fifth century BCE). ${ }^{37}$ Despite these harbingers of doom, Kükai expresses his confidence in Kunimichi's ability to bring order to the frontier:

\section{君智而謀。果而惠。門則累葉。人定平章。吐議 允聖心。衆亦推之。是故。授斧節於龍顔。撫皇 化于蝦荒。賜餞。賜詩。天澤霖然。侍坐奉和詩 則爲什。當是。暉榮史策。擧音絲竹。}

While you possess sharp intelligence and strategic prowess, you are also courageous and compassionate. Your family is an accumulation of the leaves of learning; truly you possess the qualifications of an imperial scribe. You present arguments that please the emperor, and you enjoy the support of the people as well. Therefore, you were presented the ceremonial sword by the emperor, and you will instill his virtues in the vulgar barbarians. You were given a farewell banquet and presented with poems; the emperor showered you with a deluge of benevolence. You sat before the emperor and exchanged many poems with him. Your glory shall be recorded in the history books and the rhythm of your poetry shall be set to music.

Kūkai's assertion that the Ōtomo family is "an accumulation of the leaves of learning" may be a nod to Kunimichi's ancestor Yakamochi, who is generally credited as the final compiler of the Man'yōshü. As with Minemori prior, Kūkai appeals to the power of lineage as a way to promote the legitimacy of his addressee: just as Minemori was the son of former Vice-General Ono no Nagami, Kunimichi is firmly situated within the literary and intellectual legacy of the Ōtomo clan. Also, much like Minemori, Kunimichi enjoyed an audience and poetic exchanges with the emperor. Finally, Kūkai's claim that Kunimichi's deeds will be "recorded in the history books and the rhythm of your poetry shall be set to music" is the ultimate form of praise in the Confucian universe, as history and music were viewed as

\footnotetext{
37 Nakatani, "Kūkai kanshibun no kenkyū," p. 58. He also notes that it is difficult to ascertain whether there were unusually high levels of geophysical and astronomical phenomena at the time since the relevant section of the Nihon kōki is missing (ibid).
} 
the highest forms of expression. Through this detailed narration of Kunimichi's background, Kükai declares that much like his predecessor Minemori, he is the ideal candidate to civilize the untamed northeastern frontier. He concludes his missive to Kunimichi with words of farewell and a list of gifts, followed by a poem extolling his virtues:

加之。擧城。寮族知舊。悉皆餞惜。貧道。與君 淡交。玄度遠公。緇素區別。伴佐昆季。送人以 言。古人道之。三軸祕録。一篇拙詩。加持神 藥。以弁別後之思。人至乞垂撿。春辭秋入。聖 君之明詔。載馳載驟。早奏辺烽之無塵。云爾。

In addition, your colleagues, relatives and friends throughout the city have presented you with farewell gifts and lament [your departure]. Our friendship is like plain company, ${ }^{38}$ and we are like Xuan Du and Yuan Gong. ${ }^{39}$ Although priests and laymen are separate, the Ōtomo and Saeki clans are brothers. The ancients said that a person should be sent off with words. I present you with the Three Strategies, a piece of poetry, and medicines that have been esoterically blessed. When my messenger arrives, I ask that you inspect these items. It is the emperor's esteemed wish that you depart in the spring and return in the autumn. Gallop away, gallop away! I present the following poem in the hope that you will quickly dispatch the fires and dust on the frontier.

38 Kükai uses a line from the Zhuangzi to demonstrate the depths of his friendship with Kunimichi and how it transcends the interests of the vulgar world: "Moreover, the intercourse of superior men is tasteless as water, while that of mean men is as sweet as new wine. But the tastelessness of the superior men leads on to affection, and the sweetness of the mean men to aversion" (且君 子之交淡若水小人之交甘若醴君子淡以親小人甘以絶). Watanabe and Miyasaka, Shōryōshū, p. 501; Legge, Chuang Tzu, p. 35. The character 淡 means "bland" or "simple," and describes human relations that are "refreshing" in contrast to the "cloying relations of the 'petty man which are sweet as sugar."' Pollack, The Fracture of Meaning, p. 85

39 The identity of Xuan Du 玄度 cannot be ascertained, but it may be another name for Xu Xun 許詢 (fl. ca. 358?), a Daoist poet who enjoyed mountaineering, but was also present at Wang Xizhi's 王羲之 (303-361) poetry gathering at the Orchid Pavilion 蘭亭 in 353. Watanabe and Miyasaka, Shōryōshū, 501; Imataka et al., Henjō hokki shōryōshū, p. 263.

Yuan Gong 遠公 (d.u.) was a monk who lived in the wilderness. In the poem above, Kūkai presents Xuan Du as Kunimichi, and Yuan Gong as himself. Watanabe and Miyasaka, Shōryōshū, p. 501.
君門開闢皇王將

智勇英謀允聖神

持節犯霜如松柏

含貞凌雪似竹笏

良將折衝何出塞

賢才妙略帳中陳

毛夷螘陣一把草

羽狄犲營半掬塵

飛禽也識恩將義

猛虎尚智慧與仁

治亂在吾不在敵

歸心仮意爲已身

天簡在君不須讓

忘家爲國之忠臣

鳥聲悲哢園花落

雲斾飛馳軍令申

孫子張良彼何物

六銗三略用此春

東涯萬里少一歩

一咤早馳荒服馴

Since the founding of our nation, your clan served the emperor as generals,

Your wisdom, bravery, insight and strategy are truly divine.

You possess loyalty that resists the frost, like pine or cypress,

Your righteousness withstands the snow, like bamboo.

Why does the skilled general leave the fort to engage the enemy?

Superior strategies by a brilliant talent are conceived inside a battlefield tent.

The Hairy Barbarians are like a legion of ants; they are merely a handful of grass,

The Feathered Barbarians are like a pack of wolves, merely half a handful of dust.

Birds are aware of gratitude and righteousness,

Vicious tigers know about generosity and benevolence.

Pacifying the insurrection is incumbent upon you, not the enemy

Whether they submit or revolt depends upon your intent 
The emperor has appointed you, and this appointment cannot be declined

Forgetting one's home for the nation - such is a loyal retainer

The birds cry in their sad voices and blossoms fall in the garden

War banners fly like clouds and marching orders are issued

Sun $\mathrm{Zi}$ and Zhang Liang - what are they?

The Six Secret Teachings and Three Strategies will be used this spring

The ten thousand li eastern frontier is just a step away

Just shout and gallop in on your horse - the ruffians will submit.

Kükai's declaration that "a person should be sent off with words" yet again underscores the valorization of the written word in early ninth-century Japan. Kunimichi is presented with a poem (assumedly the one appended to the epistle), and treatises on military strategy. Kūkai's cultural chauvinism is evident in the line "pacifying the insurrection is incumbent upon you, not the enemy." His attitude exudes a noblesse oblige where the Yamato Japanese bear the burden of civilizing their less-fortunate neighbors. In Kūkai's dispatches to both Minemori and Kunimichi, he emphasizes the importance of cultural colonization and assimilation, a stance that was aligned with contemporaneous Heiankyō thought. ${ }^{40}$

Kùkai's epistle and poem focuses on the literary

40 Despite sharing a number of rhetorical similarities, there is a key functional difference between the epistle-poem sets sent to Minemori and Kunimichi. Aside from congratulating Kunimichi on his new posting and extolling his many literary and martial virtues, the letter and poem sent to Kunimichi serve to politically rehabilitate the Ōtomo lineage. The Ōtomo were also known as a powerful warrior clan, and their involvement in court politics from the Nara period on led to their decline. Tabito himself was implicated in the Prince Nagaya 長屋王 (684(?)-729) incident, where members of the Fujiwara clan falsely accused the prince of treason. Naoki, "The Nara State," p. 248. The prince was sentenced to death and eventually committed suicide, and Tabito was temporarily relegated to Dazaifu and charged with pacifying the Hayato due to his association with him. Ötomo no Komaro 大 伴古麻呂 (?-757) was tortured to death for his suspected involvement in the unsuccessful plot to overthrow Empress Kōken 孝 謙 (718-770; r. 749-758, 776-770), led by Tachibana no Naramaro 橘奈良麻呂 (721(?)-757). Komaro's son was none other than the aforementioned Tsuguhito. Furthermore, while Tsuguhito was held responsible for the incident at Nagaokakyō, many historians believe that Yakamochi was actually the ringleader. Cranston, "Asuka and Nara Culture," 480; Sakaue, Ritsuryō kokka, p. 30. tradition of the Ōtomo clan, and makes no mention of their political troubles in the late eighth century. Kunimichi's ancestors are depicted as loyal servants of the emperor and the nation, leading armies into battle to subjugate barbarians on the frontier. In addition to lauding the past military accomplishments of the Ōtomo, Kūkai also lavishly praises Kunimichi's abilities as an orator and a poet: "Your glory shall be recorded in the history books and the rhythm of your poetry shall be set to music." Kūkai's testament to Kunimichi completely elides the past transgressions committed by his ancestors and recasts him as a loyal, competent retainer at the court's service. Like his predecessor Minemori, Kunimichi would return to the capital and continue to ascend the court ranks. In 826, Kunimichi supervised the completion of the Masudaike 益田池 reservoir in Yamato Province, one of the greatest civil engineering projects of the Heian period. ${ }^{41}$

\section{Conclusion}

Kūkai's epistle-poems to these literati-bureaucrats headed for the frontier demonstrate that literary works played a significant part in delineating the discursive terrain of Japan's northeastern periphery. His writings served to textually circumscribe the borders of the Heian state along the lines of a sinitic center-periphery ideology. While this idea was certainly not new, Kūkai innovated upon this concept by recasting Minemori and Kunimichi as poet-bureaucrats who would literally bring the word of civilization to the frontier. Although Kūkai certainly drew on continental precedents in formulating his arguments, he did not uncritically superimpose continental geopolitical sensibilities onto the Heian state. Particularly noteworthy is Kūkai's appropriation and reception of the rhetoric found in Tang frontier poems. In Kūkai's literary imagination, while the frontier was far from the capital and the emperor it was far from being a place of exile. Kükai recast the frontier as a productive space where the barbarians could be civilized and careers could be made.

Aside from further elucidating the linguistic and geopolitical discourses of the time, these poems are

\footnotetext{
41 Kūkai composed a memorial stele commemorating the completion of the Masudaike reservoir. The text of the stele can be found in fascicle two of the Shōryōshū. Watanabe and Miyasaka, Shōryōshū, pp. 191-96.
} 
also extremely valuable as primary source texts. First, while these poems are not doctrinal or theological per se, they add to the body of knowledge regarding one of Japan's most important religious figures. Scholars of sinospheric languages and literatures can use these texts to better understand how the continental tradition was appropriated, reimagined, and deployed in one of the sinosphere's cultural satellites. In effect, Kūkai successfully reinterpreted and transformed the Chinese model onto the Japanese linguistic and political terrain.

\section{Reference List}

- Abbreviations Used

JJS Journal of Japanese Studies

KDKZ Kōbō Daishi Kūkai zenshū 弘法大師空海全 集. 8 vols. Chikuma Shobō, 1983-1986.

KST Shintei zōho kokushi taikei 新訂増補国史大 系. 66 vols. Yoshikawa Kōbunkan, 1929-1964.

NKBT Nihon koten bungaku taikei 日本古典文学大 系. 102 vols. Iwanami Shoten, 1958-1968.

\section{- Primary and Secondary Sources}

Abé, Ryūichi. The Weaving of Mantra: Kūkai and the Construction of Esoteric Buddhist Discourse. Columbia University Press, 1999.

Ban $\mathrm{Gu}$ 班固. Baihutongyi 白虎通義. In vol. 247 of Qinding siku quanshu huiyao 欽定四庫全書薈要. Jilin: Jilin chuban jituan, 2005.

Cranston, Edwin A. "Chapter 9: Asuka and Nara Culture: Literacy, Literature and Music." In vol. 1 of Cambridge History of Japan, ed. Delmer M. Brown, pp. 453-503. Cambridge University Press, 1993.

Fan Ye 范曄 et al., Songben Houhanshu 宋本後漢書. Beijing: Guojia Tushuguan Chubanshe, 2017.

Farris, William Wayne. Heavenly Warriors: The Evolution of Japan's Military, 500-1300. Council on East Asian Studies, Harvard University, 1995.

Friday, Karl. "Pushing Beyond the Pale: The Yamato Conquest of the Emishi and Northern Japan." JJS 23:1 (1997), pp. 1-24.

Gotō Akio 後藤昭雄. “Ono no Minemori shōron” 小野 岑守小論. Nihon bungaku 日本文学 (Tokushū Nihon bungakushi ni okeru kanbungaku II 特集日本における漢 文学II) 28:7 (1971), pp. 14-20.
Hanihara Kazuo. "Emishi, Ezo, and Ainu: An Anthropological Perspective." Japan Review 1:1 (1997), pp. 35-48.

Harada Ai 原田愛. Soshi bungaku no keishō to Soshi ichizoku 蘇氏文学の継承と蘇氏一族. Fukuoka: Chūgoku Shoten, 2015.

Heldt, Gustav. The Pursuit of Harmony: Poetry and Power in Early Heian Japan. Cornell East Asia Series, 2008.

Hu Ying. "Records of Anomalies." In The Columbia History of Chinese Literature, ed. Victor H. Mair, pp. 544-45. Columbia University Press, 2001.

Hudson, Mark J. Ruins of Identity: Ethnogenesis in the Japanese Islands. University of Hawai 'i Press, 1999.

Imataka Makoto 今鷹真, Kanaoka Shūyū 金岡秀友, Kanaoka Shōkō 金岡照光, and Makio Ryōkai 牧尾良海, eds. Henjō hokki shōryōshū 遍照発揮性霊集. In KDKZ 6.

LaMarre, Thomas. Uncovering Heian Japan: An Archaeology of Sensation and Inscription. Duke University Press, 2000 .

Legge, James. The Writings of Chuang Tzu. In Sacred Books of the East, vols. 39 and 40. Oxford University Press, 1891.

Nakatani Masamitsu 中谷征充. “Kūkai kanshibun no kenkyū 'Zō Tomo azechi heishōji fu Rikufu shi narabi ni jo' no 'jo' ni okeru 'Binmō' no chūshaku no kentō” 空 海漢詩文研究「贈伴按察平章事赴陸府詩并序」の 「序」に於ける『便蒙』の注釈の検討. Kōyasan Daigaku Mikkyō Bunka Kenkyūjo kiyō 高野山大学密教文化研究 所紀要 29:1 (2016), pp. 51-66.

Naoki, Kōjirō, and Felicia G. Bock, "Chapter 4: The Nara State." In vol. 1 of Cambridge History of Japan, ed. Delmer M. Brown, pp. 221-67. Cambridge University Press, 1993.

Nihon kōki 日本後紀. KST 3 .

Nihon sandai jitsuroku 日本三大実録. 2 vols. KST 8-9.

Nishimoto Masahiro 西本昌弘. “Kusuko no hen to sono haikei”薬子の変とその景. Kokuritsu Rekishi Minzoku Hakubutsukan kenkyū hōkoku 国立歴史民俗博物館研 究報告 134 (2007), pp. 75-90.

Okamura Michio 岡村道雄. Jōmon no seikatsushi 縄文の生 活誌. Kōdansha, 2002.

Pollack, David. The Fracture of Meaning: Japan's Synthesis of China from the Eight through Eighteenth Centuries. Princeton University Press, 1986.

Ruijū kokushi 類聚国史. 2 vols. KST 5-6.

Sakaue Yasutoshi 坂上康俊. Ritsuryō kokka no tenkan to “Nihon”律令国家の転換と「日本」. Kōdansha, 2001.

Shibayama, Saeko. "Ōe no Masafusa and the Convergence of the 'Ways': The Twilight of Early Chinese Literary 
Studies and the Rise of Waka Studies in the Long

Twelfth Century in Japan." PhD Dissertation, Columbia

University, 2012.

Shoku Nihongi 続日本紀. 1 vol. KST 2.

Stockdale, Jonathan. Imagining Exile in Heian Japan:

Banishment in Law, Literature, and Cult. University of Hawai 'i Press, 2015.

Takigawa Kōji 滝川幸司. “Keikoku no bunshō 2: 'Tenron’ 'Ronbun' no juyō to chokusenshū no seiritsu” 経国の文 章(2):「典論」「論文」の受容と勅撰集の成立. In Nihon "bun" gakushi "bun" no kankyō: Bungaku izen 日本「文」 学史「文」の環境: 文学以前, ed. Kōno Kimiko 河野貴 美子 et al., pp. 338-77. Bensei Shuppan, 2017.

Watanabe Shōkō 渡辺照宏 and Miyasaka Yūshō 宮坂宥勝, eds. Sangō shiiki 三教指帰, Shōryōshū 性霊集. NKBT 71. Iwanami Shoten, 1965.

Webb, Jason. "In Good Order: Poetry, Reception, and Authority in the Nara and Early Heian Courts." PhD Dissertation, Princeton University, 2005. 